\title{
Assessment of Ground Water Quality in Shrirampur Tehsil: A GIS-Integrated Approach
}

\author{
Dr. S. P. Cholke \\ Department of Geography, R. B. N. B. College Shrirampur
}

\begin{abstract}
In recent years, an increasing threat to ground water quality due the results of man's activity at ground surface; the industries are discharging their effluents consist varies chemicals and dissolved salts more than the permissible limits with overuse of fertilizers on agricultural land coupled with overuse of water for irrigation have resulted in causing salinization of ground water. The quality of ground water depends on physical, chemical and biological factors; however, determining the overall water quality condition is difficult due to the spatial variability of multiple contaminants and the wide range of indicators, therefore, a GIS-based ground water quality index (WGQI) is one of the most effective tools to determining its suitability for drinking and agricultural purposes. It is observed that in the village Bhokar, Matapur and Eklahare has very high GWQ Index (between 13-27) therefore, water is more polluted and unsuitable for drinking due to extensive use of fertilizers, overuse of water for irrigation and discharge of molasses into the open ground. Therefore it is the need of the hour that the system of agriculture should be revitalized, to make an environmentally stronger. For this, first and foremost step is to conserve the surface and ground water where the Ground water quality is declining.
\end{abstract}

Keywords: GWQI, GIS, agriculture, fertilizer, over irrigation

\section{Introduction}

In recent years, an increasing threat to ground water quality due to human activities has become of great importance. The adverse effects on ground/water quality are the results of man's activity at ground surface; the industries are discharging their effluents consisting of dissolved salts more than the permissible limits along with overuse of fertilizers on agricultural land coupled with more usage of irrigation water have resulted in causing salinity in ground water. The quality of ground water depends on a large number of individual hydrological, physical, chemical and biological factors, therefore, the quality of ground water varies from place to place, with the depth of water table, and from season to season and is primarily governed by the extent and composition of dissolved solids present in it.

However, describing the overall water quality condition is difficult due to the spatial variability of multiple contaminants and the wide range of indicators (chemical, physical and biological). This contribution proposes a GISbased ground water quality index (WGQI) which synthesizes different available water quality data (e.g., $\mathrm{Cl}^{-}$, $\mathrm{Na}^{+}, \mathrm{Ca}^{2+}$ ) by indexing them numerically relative to the Indian standards and World Health Organization (WHO) standards. Ground Water quality index (GWQI) is one of the most effective tool to determining its suitability for drinking and agricultural purposes which is defined as a rating reflecting the composite influence of different water quality parameters and becomes an important parameter for the assessment and management of groundwater.

\section{Study Area}

Shrirampur Tahsil is located in the North part of Ahmednagar district of Maharashtra state and is extended between $19^{\circ} 45$ to $20^{\circ} 30 \mathrm{~N}$ latitudes and $74^{\circ} 00$ to $74^{\circ} 30 \mathrm{E}$ longitudes. The total geographical area of the tahsil is $579.87 \mathrm{sq} . \mathrm{km}$ which covers 54 villages. The net cultivated area in $2006-07$ was 480 sq. $\mathrm{km}$. About $70 \%$ of the area is irrigated by canal and dug wells, putting high pressure on groundwater resources of the Tahsil. The total population of tahsil is 2, 56,441 (Census, 2001) and almost $80 \%$ of the workforce is engage in the agriculture, horticulture, animal husbandry and Sugar Industries. The Tahsil has a subtropical monsoon climate. March, April, and May are the hottest months while December and January are the coldest. The maximum temperature recorded during summers is about $44^{\circ} \mathrm{C}$ and it is as low as $8^{\circ} \mathrm{C}$ in winters. The Tahsil receives an approximate average rainfall of $550 \mathrm{~mm}$ and more than $75 \%$ of which occurs during the monsoon period (July-September). The important rivers/streams traversing the tahsil are Pravara and Godavari. Last few decades, the use of chemicals and fertilizers has increased to enhance the yield of sugarcane crop. The pollutants of these pesticides leach through soil to reach the water table. There is a main environmental issue due to depleted quality of surface water resources in the river that has been polluted to a large extent. The groundwater resources are also being polluted because of surface water pollution through over irrigation, high consumption of chemical fertilizers and agro based industry.

\section{Methodology}

The present study has been carried out in following two stages

\section{Stage 1 - Groundwater sample collection:}

Fifty Two water samples were collected in $1000 \mathrm{ml}$ volume from different wells, tube wells and hand pumps from different villages in Shrirampur Tahsil in January 2010. The water level of dug-well was measured by simple measuring tape. Simultaneously, GPS readings were taken for latitude, longitude, and height above mean sea level (MSL). After sampling, collected samples were immediately brought to analytical laboratory and stored and further, analysis was started without delay. 


\section{International Journal of Science and Research (IJSR) \\ ISSN (Online): 2319-7064}

Index Copernicus Value (2013): 6.14 | Impact Factor (2015): 6.391

\section{Stage 2 - Integrated GIS Analysis of Groundwater samples:}

Each of the groundwater samples was analyzed for 13 parameters such as $\mathrm{pH}$, Electrical Conductivity (EC), TDS, Total Hardness (TH), Sodium (Na+), Potassium (K), Calcium (Ca), Magnesium (Mg), Total Alkalinity (TA) as $\mathrm{HCO} 3$, Chloride $(\mathrm{Cl})$, phosphate $\left(\mathrm{PO}_{4}\right)$, Sulphate $\left(\mathrm{SO}_{4}\right)$ and Iron $(\mathrm{F})$ using standard procedures, details are presented in Table. The range of variation of water quality parameters for different sampling stations of the tahsil, were assigned subjective weights to evolve composite ground water quality index (CGQI) for different stations. The range of subjective weight varied from 1 to 5 , a weight of 1 indicate good water quality and weight of 5 means highly polluted ground water quality. The total CGQI values where obtained by summing the water quality weights of individual water quality parameters to enable evaluation of extent of water pollution and its spatial variation for the area corresponding to different villages

A Potential GWQI map generated in the ArcGIS 9.3 for the area using spatial interpolation techniques can give an assessment regarding the spatial variation of different water quality parameters associated with different water quality factors.

\section{Results and Discussions}

The chemical analyses of the groundwater sample of 52 villages are summarized respectively in Table No.1 and GWQI scores are presented in Table 2. GWQ Index map is generated in the ArcGIS 9.3 with regarding the spatial variation of different water quality parameters associated with different water quality factors.

Table 1: The ground water quality data pertaining to the 50villages of Shrirampur tahsil

\begin{tabular}{|c|c|c|c|c|c|c|c|c|c|c|c|c|c|}
\hline ID & pH & EC & TDS & TH & $\mathbf{N a}$ & $\mathbf{K}$ & Ca & Mg & $\mathrm{HCO3}$ & Cl & SO4 & NO3 & $\mathbf{F}$ \\
\hline 1 & 8.1 & 3968 & 2070 & 295.2 & 113.8 & 6.8 & 12.1 & 59.2 & 782.8 & 464.5 & 32.8 & 50.8 & 1.7 \\
\hline 2 & 7.5 & 949 & 1840 & 247.6 & 106.5 & 6.9 & 23.3 & 48.8 & 686.7 & 144.0 & 20.5 & 42.0 & 1.1 \\
\hline 3 & 8.1 & 1214 & 1190 & 249.7 & 104.7 & 5.8 & 19.3 & 53.3 & 851.5 & 136.1 & 39.4 & 56.6 & 0.9 \\
\hline 4 & 8.0 & 2101 & 2170 & 292.2 & 109.3 & 2.5 & 25.7 & 74.1 & 734.8 & 366.6 & 57.5 & 53.1 & 0.9 \\
\hline 5 & 8.2 & 2764 & 1020 & 183.6 & 99.3 & 1.8 & 20.9 & 38.1 & 600.5 & 426.0 & 36.7 & 49.2 & 1.3 \\
\hline 6 & 7.7 & 1336 & 2150 & 263.1 & 120.1 & 1.1 & 18.5 & 37.8 & 519.9 & 149.1 & 17.9 & 56.6 & 0.8 \\
\hline 7 & 8.1 & 2448 & 830 & 199.5 & 157.5 & 2.8 & 14.5 & 41.0 & 573.0 & 346.0 & 362.0 & 20.7 & 1.2 \\
\hline 8 & 7.8 & 1958 & 1030 & 228.0 & 115.6 & 1.0 & 17.7 & 45.3 & 597.4 & 262.7 & 46.3 & 54.9 & 1.1 \\
\hline 9 & 7.9 & 1438 & 1330 & 354.5 & 111.1 & 2.6 & 17.7 & 69.9 & 391.4 & 222.5 & 80.6 & 34.1 & 1.2 \\
\hline 10 & 7.7 & 1428 & 1290 & 243.2 & 102.9 & 0.4 & 61.8 & 46.4 & 652.4 & 229.1 & 57.3 & 43.1 & 0.8 \\
\hline 11 & 7.9 & 2795 & 1170 & 186.1 & 98.4 & 1.3 & 25.7 & 26.1 & 563.1 & 179.9 & 40.3 & 49.2 & 1.2 \\
\hline 12 & 7.6 & 1438 & 1080 & 235.6 & 236.5 & 1.1 & 15.3 & 43.9 & 666.1 & 203.6 & 62.0 & 23.1 & 1.1 \\
\hline 13 & 7.9 & 2244 & 1190 & 295.3 & 243.7 & 4.0 & 29.7 & 54.2 & 609.2 & 40.8 & 67.1 & 53.1 & 1.3 \\
\hline 14 & 7.6 & 1846 & 1110 & 234.2 & 252.8 & 5.3 & 12.1 & 46.5 & 701.0 & 101.3 & 52.4 & 54.9 & 1.3 \\
\hline 15 & 8.3 & 1795 & 540 & 154.0 & 223.9 & 0.2 & 29.7 & 28.6 & 810.3 & 67.3 & 22.7 & 60.2 & 1.3 \\
\hline 16 & 7.7 & 1724 & 1280 & 177.1 & 106.5 & 0.6 & 19.3 & 27.3 & 453.2 & 114.6 & 77.8 & 57.3 & 0.9 \\
\hline 17 & 7.3 & 1071 & 1630 & 330.1 & 115.6 & 0.6 & 19.3 & 57.6 & 487.6 & 188.4 & 84.4 & 59.8 & 1.1 \\
\hline 18 & 8.1 & 2336 & 1120 & 211.9 & 97.5 & 2.5 & 38.5 & 41.4 & 549.4 & 126.0 & 77.1 & 50.7 & 1.1 \\
\hline 19 & 7.7 & 1836 & 1620 & 239.3 & 88.5 & 1.8 & 44.9 & 36.7 & 391.4 & 99.4 & 85.2 & 54.9 & 1.2 \\
\hline 20 & 8.2 & 1673 & 2100 & 351.7 & 97.5 & 1.8 & 30.5 & 61.4 & 501.3 & 107.0 & 89.6 & 60.2 & 0.9 \\
\hline 21 & 7.5 & 2356 & 660 & 188.7 & 115.6 & 1.6 & 24.9 & 34.5 & 377.6 & 116.5 & 35.7 & 50.7 & 0.9 \\
\hline 22 & 8.0 & 1346 & 1770 & 379.4 & 74.1 & 0.4 & 55.4 & 72.5 & 535.6 & 148.7 & 85.9 & 13.1 & 1.1 \\
\hline 23 & 7.4 & 1907 & 1770 & 398.8 & 92.1 & 1.3 & 16.9 & 80.0 & 515.0 & 78.6 & 126.0 & 54.9 & 0.8 \\
\hline 24 & 7.7 & 1693 & 2020 & 391.2 & 120.1 & 7.0 & 24.9 & 69.9 & 528.8 & 102.3 & 93.0 & 69.2 & 1.2 \\
\hline 25 & 7.9 & 2101 & 920 & 207.4 & 81.3 & 1.1 & 26.5 & 31.2 & 487.6 & 156.2 & 78.4 & 53.1 & 1.1 \\
\hline 26 & 8.0 & 1907 & 1080 & 242.4 & 195.0 & 4.3 & 16.9 & 36.8 & 624.9 & 98.5 & 74.9 & 44.9 & 0.9 \\
\hline 27 & 8.1 & 520 & 600 & 200.0 & 62.3 & 0.6 & 32.1 & 15.6 & 412.0 & 71.0 & 73.4 & 7.3 & 1.1 \\
\hline 28 & 7.7 & 1214 & 800 & 350.0 & 82.1 & 1.1 & 60.1 & 26.8 & 257.5 & 149.1 & 71.4 & 56.6 & 1.1 \\
\hline 29 & 7.7 & 673 & 400 & 205.0 & 67.7 & 0.6 & 60.1 & 12.7 & 360.5 & 56.8 & 73.0 & 26.9 & 1.1 \\
\hline 30 & 8.0 & 1408 & 900 & 255.0 & 124.5 & 1.1 & 40.1 & 20.0 & 463.5 & 156.2 & 71.7 & 13.1 & 1.1 \\
\hline 31 & 7.7 & 1173 & 1800 & 275.0 & 100.2 & 2.8 & 32.1 & 22.9 & 566.5 & 42.6 & 71.7 & 41.2 & 1.1 \\
\hline 32 & 7.7 & 3111 & 3200 & 470.0 & 343.9 & 1.3 & 32.1 & 41.9 & 566.5 & 589.3 & 71.1 & 52.3 & 1.1 \\
\hline 33 & 8.1 & 2173 & 1600 & 375.0 & 204.0 & 1.3 & 28.1 & 33.1 & 463.5 & 326.6 & 71.5 & 53.1 & 1.1 \\
\hline 34 & 7.8 & 887 & 1600 & 110.0 & 110.1 & 0.8 & 28.1 & 7.3 & 309.0 & 106.5 & 72.0 & 56.2 & 1.1 \\
\hline 35 & 7.8 & 632 & 400 & 185.0 & 79.4 & 1.1 & 52.1 & 11.7 & 360.5 & 42.6 & 72.6 & 21.3 & 1.1 \\
\hline 36 & 7.7 & 2540 & 2000 & 715.0 & 232.9 & 1.1 & 100.2 & 57.5 & 412.0 & 177.5 & 70.6 & 39.9 & 1.1 \\
\hline 37 & 7.8 & 785 & 400 & 235.0 & 82.1 & 0.6 & 32.1 & 19.0 & 257.5 & 85.2 & 71.7 & 30.1 & 1.1 \\
\hline 38 & 7.5 & 3356 & 2400 & 815.0 & 232.9 & 1.7 & 112.2 & 65.8 & 463.5 & 85.2 & 70.7 & 68.1 & 1.1 \\
\hline 39 & 7.9 & 969 & 700 & 265.0 & 102.0 & 0.8 & 32.1 & 21.9 & 257.5 & 142.0 & 70.9 & 12.0 & 1.1 \\
\hline 40 & 7.6 & 1142 & 700 & 280.0 & 93.0 & 0.8 & 48.1 & 21.4 & 463.5 & 120.7 & 71.8 & 59.8 & 1.1 \\
\hline 41 & 8.1 & 1785 & 1000 & 375.0 & 120.0 & 0.9 & 28.1 & 33.1 & 360.5 & 255.6 & 71.5 & 60.2 & 1.1 \\
\hline 42 & 7.7 & 979 & 700 & 325.0 & 70.4 & 0.6 & 40.1 & 26.8 & 257.5 & 120.7 & 71.6 & 73.8 & 1.1 \\
\hline 43 & 7.7 & 1071 & 700 & 315.0 & 89.4 & 0.6 & 16.0 & 28.8 & 360.5 & 106.5 & 71.9 & 56.1 & 1.1 \\
\hline 44 & 7.7 & 10271 & 8600 & 1710.0 & 1236.5 & 4.9 & 124.2 & 151.5 & 463.5 & 1114.7 & 71.1 & 15.0 & 1.1 \\
\hline
\end{tabular}

\section{Volume 5 Issue 5, May 2016}




\section{International Journal of Science and Research (IJSR) \\ ISSN (Online): 2319-7064}

Index Copernicus Value (2013): 6.14 | Impact Factor (2015): 6.391

\begin{tabular}{|l|c|c|c|c|c|c|c|c|c|c|c|c|c|}
45 & 7.7 & 2509 & 1800 & 575.0 & 211.2 & 0.8 & 32.1 & 52.1 & 515.0 & 355.0 & 70.8 & 50.7 & 1.1 \\
\hline 46 & 7.7 & 2836 & 2400 & 655.0 & 227.4 & 1.1 & 40.1 & 59.0 & 669.5 & 426.0 & 70.7 & 49.2 & 1.1 \\
\hline 47 & 7.5 & 5773 & 5000 & 945.0 & 1056.0 & 1.9 & 184.4 & 69.7 & 206.0 & 908.8 & 70.5 & 44.5 & 1.1 \\
\hline 48 & 8.0 & 408 & 400 & 275.0 & 57.8 & 0.6 & 28.1 & 23.4 & 257.5 & 71.0 & 71.5 & 39.8 & 1.1 \\
\hline 49 & 7.5 & 3733 & 2800 & 875.0 & 338.4 & 1.3 & 88.2 & 74.6 & 257.5 & 461.5 & 70.7 & 50.8 & 1.1 \\
\hline 50 & 7.7 & 806 & 400 & 270.0 & 71.3 & 0.6 & 32.1 & 22.4 & 206.0 & 177.5 & 71.9 & 44.4 & 1.1 \\
\hline
\end{tabular}

(Source: Computed by the Author)

Table 2: Water quality classification based on GWQ Index Score

\begin{tabular}{|c|c|c|}
\hline $\begin{array}{l}\text { GWQ } \\
\text { Score }\end{array}$ & Water quality & Name of Villages \\
\hline 0 to 2.9 & Excellent & Kadit BK, Khokar, Karegaon, Matul Than, Khandala, Khanapur Takalibhan \\
\hline 2.9 to 4.3 & Good water & $\begin{array}{l}\text { Nimgaon Khairi, Mankal Wadgaon, Bhamathan, Undirgaon, Mal Wadgaon, Barhmangaon, Dighi, } \\
\text { Shrirampur, Belapur, Mandve, Gondhavani, Kadit }\end{array}$ \\
\hline 4.3 to 7.2 & Poor water & $\begin{array}{c}\text { Gujarwadi, Bheradapur, Pedegaon, Fatyabad, Ainatpur, Nipani Wadgaon, Kanhegaon, Wangi Kh. } \\
\text { Haregaon, Gumandeo, Malewadi, }\end{array}$ \\
\hline 7.2 to 13 & Very poor water & $\begin{array}{c}\text { Naur, Rampur, Kamalpur, Wadala Mahadeo, Khridi, Malunje Bk, Ladgaon, Uambargaon, Wadatgaon, } \\
\text { Kurranpur, Gondegaon, Galnimb, Ukkhalgaon, Nursari }\end{array}$ \\
\hline 13 to 27 & $\begin{array}{l}\text { Unsuitable } \\
\text { for Drinking }\end{array}$ & Bhokar, Matapur, Eklahare, \\
\hline
\end{tabular}

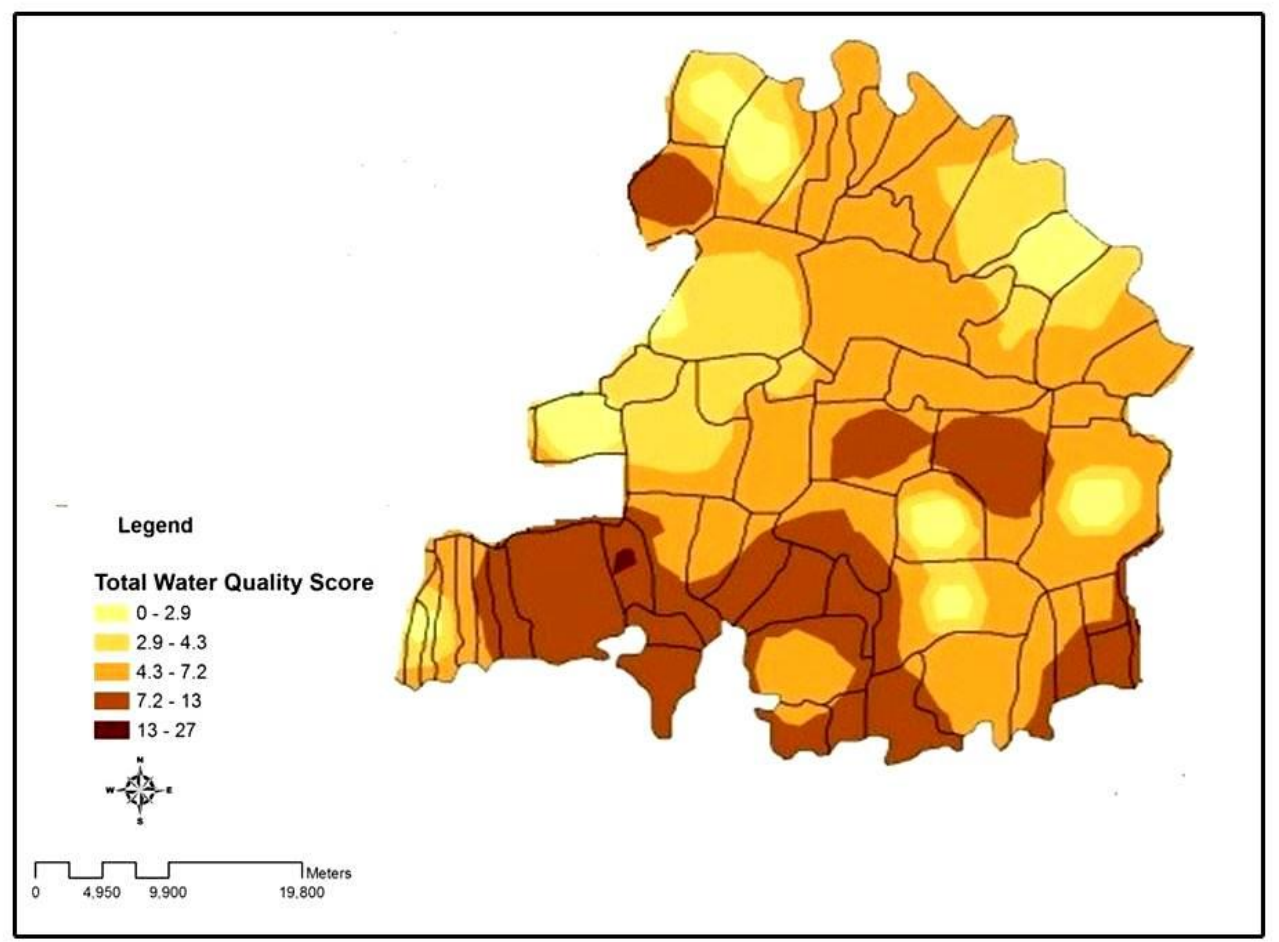

Figure 1: Ground Water Quality of Shrirampur Tehsil

The GWQ Index indicated that the electrical conductivity (EC) of the water is high due to presence of more dissolved salts in it. The water is alkaline in the area with concentration of $\mathrm{Na}+, \mathrm{K}+\mathrm{Ca}+, \mathrm{Cl}-, \mathrm{Mg}+, \mathrm{SO} 4$, carbonates etc., generally exceeding the CPCB standards. It is observed that in the village Bhokar, Matapur and Eklahare has very high GWQ Index (between 13-27) therefore, water is more polluted and unsuitable for drinking due to extensive use of fertilizers and over irrigation in agriculture and discharge of molasses into the open ground. In the villages Naur, Rampur, Kamalpur, Wadala Mahadeo, Khridi, Malunje Bk, Ladgaon, Uambargaon, Wadatgaon, Kurranpur, Gondegaon, Galnimb, Ukkhalgaon and Nursari was recorded high GWQ Index (between 7.2-.13) due to the water quality is very poor. Takalibhan, Kadit BK, Khokar, Karegaon, Matul Than, Khandala and Khanapur villages has been observed very low GWQ Index (between 0-2.9) with excellent water which is more suitable for drinking and agricultural purposes.

Therefore it is the need of the hour that the system of agriculture should be revitalized, to make an environmentally stronger. For this, first and foremost step is to conserve the surface and ground water where the Ground water quality is declining.

\section{References}

[1] CGWB and CPCB (2000): Status of Ground Water Quality and Pollution Aspects in NCT-Delhi, January 2000.

[2] C. R. Ramakrishnaiah (2009): Assessment of Water Quality Index for the Groundwater in Tumkur Taluk, 


\section{International Journal of Science and Research (IJSR) \\ ISSN (Online): 2319-7064}

Index Copernicus Value (2013): 6.14 | Impact Factor (2015): 6.391

Karnataka State, India, E-Journal of Chemistry, 2009, 6(2), 523530

[3] Chaudhary, B. S., Kumar, M.,Roy, A. K., \& Ruhal, D.

S. (1996). Applications of RS and GIS in groundwater investigations in Sohna Block, Gurgaon District, Haryana, India. International Archives of Photogrammetry and Remote Sensing, 31(B-6), 18-23.

[4] Cholke S. P. (2012): Village Information System (V.I.S.) for watershed management in the North Ahmednagar district, Maharashtra, unpublished Ph.D. Thesis, Pune University, Pune,

[5] Goyal, S. K., Chaudhary, B. S., Singh O., Sethi, G. K., \& Thakur, P. K. (2010). GIS based spatial distribution mapping and suitability evaluation of groundwater quality for domestic and agricultural purpose in Kaithal district, Haryana state, India J. Of Environ Earth Sci 61:1587-1597

[6] WHO: Guidelines for drinking water quality, 2nd Ed., 1993, Vol 1, p 188.

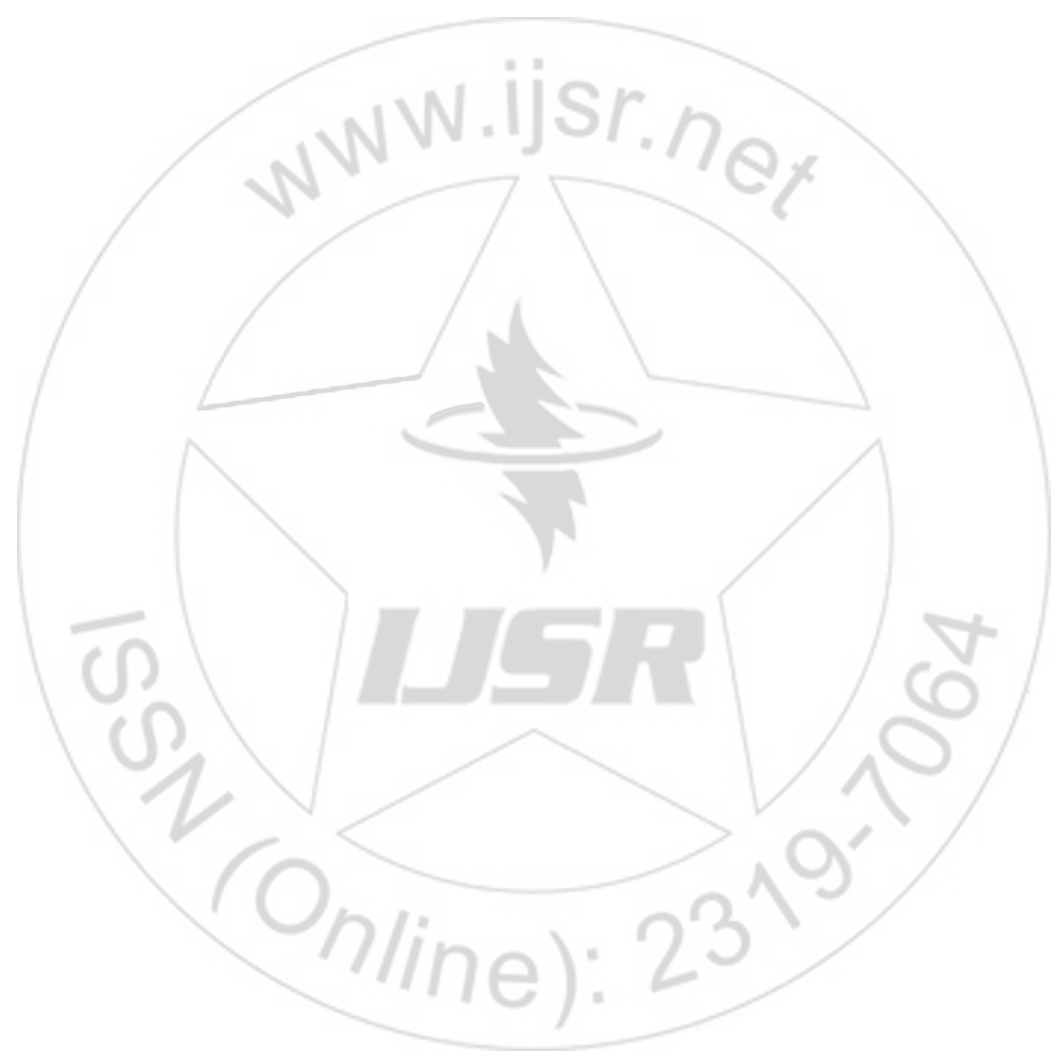

